\title{
Reviews of botulinum toxin products in aesthetic use must be accurate, clear and avoid speculation
}

This article was published in the following Dove Press journal:

Clinical Pharmacology: Advances and Applications

4 September 2013

Number of times this article has been viewed

\section{Andy Pickett ${ }^{1,2}$ \\ 'Toxin Science Limited, Wrexham, UK; ${ }^{2}$ Botulinum Research Center, University of Massachusetts (UMASS), North Dartmouth, MA, USA}

Correspondence: Andy Pickett

Toxin Science Ltd, 17 The Sycamores, Chester Road, Wrexham LLI2 8DU, UK Tel +44 792I I64 537

Email andy@toxinscience.com

\section{Dear editor}

One of the most surprising and, at the same time, most frustrating aspects of the continual rise in the use of botulinum toxin type A (BoNT-A), particularly in aesthetic applications, is the sheer number of reviews currently being published. So far in 2013, there have been seven single or joint reviews of BoNT products focusing on facial aesthetics.

The frustrating aspects of these reviews cover two areas: Firstly, they inevitably speculate about why there are "apparent differences" between the products. They attempt to use the science of BoNT-A to explain these differences. This speculation is both inappropriate and weak. In fact, the majority of differences between the products seen clinically are, by far, due to simple dose differences used in studies, especially when two or more products are being compared.

Secondly, these reviews usually have tables of data about the products which contain, according to the authors, "clinically relevant" information. They are claimed as "pharmacologic differences". Again inevitably, they are not. The data are mostly irrelevant to clinical practice and, by far the worst situation, they are actually incorrect. Readers are presented with data that are sometimes not even referenced and clearly have not been cross-checked with the appropriate sources - such as the manufacturers' own product literature.

The latest review by Prager ${ }^{1}$ is yet another publication that shows both these traits. Speculation is yet again used, for example, to propose that other components of the BoNT-A protein complex (in certain products) may lead to an increase in neutralizing antibody formation. This speculation is not based on even initial facts or data. Citations of work purporting to support this "hypothesis" are fundamentally flawed, as recently reported. ${ }^{2}$ Given that Merz Pharmaceuticals GmbH themselves, the sponsors of the Prager review, have already proven that any BoNT-A complex (BoNT-A neurotoxin and other associated proteins produced by the bacteria) is fully dissociated in the product vials before injection, ${ }^{3}$ then the concept of differential neutralizing antibody formation seems a quite inappropriate attempt at product differentiation for marketing.

The table of product data presented by Prager (Table 2$)^{1}$ which gives the characteristics of the different products, is a fundamentally flawed part of this review.

To start with (and also applicable even to the title of the paper), the United States approved names for the products (incobotulinumtoxinA, onabotulinumtoxinA, abobotulinumtoxinA) have been used. Why? These names are only applicable to the 
United States and have no relevance in Europe. They are not generic drug names since there is no such thing as a "generic biologic" product of BoNT-A. The BoNT-A products are each considered very individual and the units of potency are not interchangeable, as required by the regulatory authorities worldwide. Dr Prager is a German clinician, working in Germany, the writers of the article are based in the UK, the sponsor of the article is a German company. Europe has managed perfectly well with the original product trade names for 25 years, so why are these names used by Prager?

There are six full lines of Table $2^{1}$ with either incorrect or clinically irrelevant data. Even potentially useful clinical information is based upon either incorrect sources or single sources which do not take into account, for example, the differences in dose units of the products.

In particular, the continuing and highly confusing information being supplied in reviews about the so-called "toxin complex size" is given by Prager, yet again. ${ }^{1}$ But, once more, the data already produced by Merz Pharmaceuticals GmbH show this is totally irrelevant when considering the BoNT-A products in clinical use, due to dissociation within the vial prior to injection. $^{3}$

Prager has additionally failed to recognize that Galderma is the company marketing Azzalure ${ }^{\circledR}$ within Europe, not Ipsen or Medicis, which is very strange given that Galderma and Azzalure ${ }^{\circledR}$ are strongly represented in Germany. Previous comments in an earlier review by Prager et al, ${ }^{4}$ that "the number of abobotulinumtoxinA injections was so low (1.6\%, which might reflect daily practice in Germany)" are quite ludicrous. The number of Azzalure ${ }^{\circledR}$ units per vial (125 Speywood units) is not even cited. Such errors, omissions and comments are highly misleading and ingenuous for readers.

Finally, if the storage temperature of Xeomin ${ }^{\circledR} /$ Bocouture $^{\circledR}$ (Merz Pharma GmbH \& Co. KGaA, Frankfurt, Germany) does rise above $25^{\circ} \mathrm{C}$, then refrigeration of those products will be required. A statement "no refrigeration required" cannot be made, as in Table 2 of Prager. ${ }^{1}$ Merz ship their BoNT-A products to warmer countries in specialized, temperature-controlled packaging in order to keep the product within the approved storage conditions, as per the manufacturers instructions. The reader should refer to the relevant storage data for their own country of use.

All of these errors in the Prager review ${ }^{1}$ could and should be both avoided and prevented. Tables of such data are regrettably taken by many readers and users of BoNT-A products as definitive sources of information and so must be correct. These issues of error have been raised by myself and others before, yet their continual publication still continues. ${ }^{2,5,6}$

However what is the final and perhaps most strange aspect of this review is that, given the Merz sponsorship, there should be no errors and no speculation about the BoNT-A products. There is no place for such failures in the world of evidence-based product assessments today.

\section{Disclosure}

The author is Director and Founder of Toxin Science Limited, Wrexham, UK and Adjunct Professor at the Botulinum Research Center, UMASS Dartmouth, Dartmouth, USA. He is also Head of Development for Q-Med AB, a Galderma Division.

The opinions and comments expressed in this article are those of the author and Toxin Science Limited alone.

\section{References}

1. Prager W. Differential characteristics of incobotulinumtoxinA and its use in the management of glabellar frown lines. Clin Pharmacol. 2013;5:39-52.

2. Pickett A. Immunogenicity issues related to botulinum toxins in clinical use cannot be answered by speculation about product characteristics. BioDrugs. 2013;27(1):83-84.

3. Eisele K-H, Fink K, Vey M, Taylor HV. Studies on the dissociation of botulinum neurotoxin type A complexes. Toxicon. 2011;57(4):555-565.

4. Prager W, Huber-Vorlander J, Taufig AZ, et al. Botulinum toxin type A treatment to the upper face: retrospective analysis of daily practice. Clin Cosmet Investig Dermatol. 2012;5:53-58.

5. Pickett A, Caird D. Comparison of type a botulinum toxin products in clinical use. J Clin Pharm Ther. 2008;33(3):327-328.

6. Pickett A. Inability of speculation to explain dose effect differences between botulinum toxin products. Arch Facial Plast Surg. 2012;14(6): $467-468$. 


\section{Author's response}

\author{
Welf Prager \\ Dermatologikum Hamburg, Hamburg, Germany
}

Correspondence: Welf Prager

Dermatologikum Hamburg, Stephansplatz 5, 20354 Hamburg, Germany

Tel +494035I0 757I

$\mathrm{Fax}+494035107510$

Email prager@dermatologikum.de

\section{Dear editor}

I would like to respond to the letter by Andy Pickett in relation to the review entitled 'Differential characteristics of incobotulinumtoxinA and its use in the management of glabellar frown lines'. ${ }^{1}$ While several criticisms were made, there were few actual details of specific points on which I can comment but I will deal with any that were made below.

First, I would like to address the comment made about the relevance of toxin complex size. While it is the case, as acknowledged, that the complexing proteins contained in some formulations of botulinum toxin type A (BoNT/A) dissociate within the vial prior to injection, ${ }^{2}$ these complexing proteins are nonetheless injected along with the neurotoxin and, therefore, should not be dismissed as irrelevant. Certainly, due to this dissociation, they serve no beneficial role in terms of stabilizing the neurotoxin or protecting it from degradation. However, they are not irrelevant in terms of resulting in onabotulinumtoxinA representing a larger foreign protein load than that represented by incobotulinumtoxinA (which is free from complexing proteins) when the same number of units are administered. In 2003, Jankovic et al compared the immunogenicity of the original preparation of onabotulinumtoxinA used prior to 1998 , which contained $25 \mathrm{ng}$ of protein per $100 \mathrm{U}$, with the newer formulation that contains only $5 \mathrm{ng}$ protein per $100 \mathrm{U} .^{3} \mathrm{In}$ patients with cervical dystonia, Jankovic et al found that four out of 42 patients treated only with the original onabotulinumtoxinA preparation developed neutralizing antibodies, as detected by the mouse protection assay, but no patients out of 119 treated only with the newer formulation developed immunoresistance. They concluded that this provided strong evidence that the original formulation of onabotulinumtoxinA was markedly more antigenic than the newer formulation, suggesting that protein loading is an important risk factor for the development of immunoresistance. ${ }^{3}$ It has been suggested by Pickett that it was the removal of inactive BoNT/A from the original onabotulinumtoxinA, not a reduction in protein load per se, that is responsible for this effect. ${ }^{4}$
However, from these data it is not possible to distinguish between these two alternative explanations, and there are no experimental data in the literature to support the claim that it was inactive neurotoxin that was removed. In addition, it has been shown that certain hemagglutinin components of the BoNT type B complex are immunostimulatory and enhance the production of anti-neurotoxin antibodies in mice. ${ }^{5}$ Therefore, one hypothesis is that a higher amount of dissociated complexing proteins injected along with the type A neurotoxin could result in a greater risk of neutralizing antibody production via an adjuvant effect, though this has yet to be tested. Alternatively, even if the removal of inactive neurotoxin from onabotulinumtoxinA was responsible for the reduced risk of neutralizing antibody production, it was recently shown that onabotulinumtoxinA contains some inactive neurotoxin, while incobotulinumtoxinA is likely to contain only active neurotoxin. ${ }^{6}$ Although immunogenicity can be seen as less important in aesthetics than in therapeutic indications where higher doses are administered, the toxin complexes and the foreign protein load they represent are not clinically irrelevant.

Given Pickett's connections with Galderma, (he is Director and founder of Toxin Science Ltd, and Head of Development for Q-Med AB, a Galderma Division) it is natural he would pick up on related issues. As was stated correctly in the review in question, Ipsen Ltd, markets Dysport ${ }^{\circledR}$ in Europe. ${ }^{1}$ Ipsen Ltd, is also marketing authorization holder for Azzalure ${ }^{\circledR}$ in Europe however, as was pointed out, Galderma (UK) Ltd, markets Azzalure ${ }^{\circledR}$ in Europe. ${ }^{7}$ In addition it should be added that Azzalure ${ }^{\circledR}$ is available in $125 \mathrm{U}^{\text {vials. }}{ }^{7}$

On the issue of storage conditions, the description of the temperature requirements for incobotulinumtoxinA storage stated in the review is correct. As mentioned in Table 2, incobotulinumtoxinA can be stored 'up to $25^{\circ} \mathrm{C}$ (no refrigeration required)', which is accurate and clear. ${ }^{1}$ Refrigeration commonly refers to maintaining the temperature between $2^{\circ} \mathrm{C}$ and $8^{\circ} \mathrm{C}$, which is not a requirement for incobotulinumtoxin $\mathrm{A}$ storage - it can be stored up to $25^{\circ} \mathrm{C}$ and does not need to be kept between 2 and $8^{\circ} \mathrm{C}$. In fact, as was reported in a recent thermostability study discussed in the review, incobotulinumtoxinA was unaffected by short-term temperature stress (up to 1 month) between $45^{\circ} \mathrm{C}$ and $60^{\circ} \mathrm{C} .{ }^{8}$

Criticism was also made of the use of the terms incobotulinumtoxinA, onabotulinumtoxinA and abobotulinumtoxinA. However, this terminology was applied to avoid the use of brand names in light of the Dove Press author guidelines requesting the use of generic terms, and to comply with the journal's suggestion to use this nomenclature. In addition 
this seems an insignificant point when it is the scientific and clinical information in the review that is of key importance to the reader.

Despite the assertion that six lines of Table 2 were 'incorrect' or 'clinically irrelevant', not all perceived issues were identified or described in detail, making it impossible to comment on each individually. Those that were mentioned specifically are addressed in this response. Differences do exist between the different commercially available BoNT/A formulations, such as the presence or absence of complexing and other clostridial proteins. The purpose of Table 2 from the review in question was to display certain characteristics of the available BoNT/A preparations. It was not described as showing 'pharmacological differences'.

The aim of the article discussed here was to describe the differential characteristics of incobotulinumtoxinA, provide a comprehensive review of the available data, and summarize interesting scientific and clinically useful information for readers based purely on research of the clinical literature and experience in daily practice.

\section{Acknowledgments}

Editorial assistance was provided by Ogilvy 4D, Oxford, UK, supported by Merz Pharmaceuticals GmbH.

\section{Disclosure}

Welf Prager has acted as a consultant and lecturer for Allergan Inc, Merz Pharmaceuticals GmbH and Galderma Pharma SA.

\section{References}

1. Prager W. Differential characteristics of incobotulinumtoxinA and its use in the management of glabellar frown lines. Clin Pharmacol. 2013; 5:39-52.

2. Eisele K-H, Fink K, Vey M, Taylor HV. Studies on the dissociation of botulinum neurotoxin type A complexes. Toxicon. 2011;57(4):555-565.

3. Jankovic J, Vuong KD, Ahsan J. Comparison of efficacy and immunogenicity of original versus current botulinum toxin in cervical dystonia. Neurology. 2003;60(7):1186-1188.

4. Pickett A. Immunogenicity issues related to botulinum toxins in clinical use cannot be answered by speculation about product characteristics. BioDrugs. 2013;27(1):83-84.

5. Lee JC, Yokota K, Arimitsu H, et al. Production of anti-neurotoxin antibody is enhanced by two subcomponents, HA1 and HA3b, of Clostridium botulinum type B $16 \mathrm{~S}$ toxin-haemagglutinin. Microbiology. Nov 2005;151(Pt 11):3739-3747.

6. Frevert J. Content of botulinum neurotoxin in Botox $^{\circledR} /$ Vistabel $^{\circledR}$, Dysport ${ }^{\circledR} /$ Azzalure $^{\circledR}$, and Xeomin ${ }^{\circledR} /$ Bocouture $^{\circledR}$. Drugs R D. 2010;10(2):67-73.

7. Azzalure $^{\circledast}$. [summary of product characteristics]. Galderma (UK) Ltd, Hertfordshire, UK; 2010.

8. Grein SMG, Fink K. Stability of botulinum neurotoxin type A, devoid of complexing proteins. The Botulinum Journal. 2011;2(1):49-58.
Clinical Pharmacology: Advances and Applications

\section{Publish your work in this journal}

Clinical Pharmacology: Advances and Applications is an international, peer-reviewed, open access journal publishing original research, reports, reviews and commentaries on all areas of drug experience in humans. The manuscript management system is completely online and includes a very quick and fair peer-review system, which is all easy to use.

\section{Dovepress}

Visit http://www.dovepress.com/testimonials.php to read real quotes from published authors. 